\title{
udaya and pralaya in the Spanda-sāstra
}

\section{Hirohisa TODA}

The doctrine of spanda is well known as a characteristic view of Kashmiri Saivism as is the doctrine of pratyabhijñ $\bar{a}$. There are broadly speaking two opinions among modern scholars about the relation between the system of Spanda and that of Pratyabhijñā: either they are independent systems or the former is a branch-system of the latter. In this paper, I will illustrate an instance of modification of the original doctrine of spanda by the later commentators.

〈1〉 In Spandakārikāabbr. to SpK) 1, Śamkara is extolled as following:

We praise that Śamkara (=Ś Śiva) by whose opening (unmeșa) and closing (nimeșa) [of eyes or will-power] there is production (udaya) and destruction (pralaya) of the world and who is the source of the glorious powers of the wheel of energies. According to Kallața's Vrtti, the equivalents of udaya and pralaya are respectively utpatti (occurring) and saṃhāra (withdrawing). He explains the point of the next verse ( $\mathrm{SpK} 2)$ to be that any transmigrators (samsārin) are nothing but Śiva Himself. And yet he considers Siva to be the cause of arising and continuing of the world in reality. $\mathrm{He}$ might have recollected the three great functions (krtya) attributed to the Supreme God, commonly known by the terms srsți (creation), sthiti (maintenance) and samhāara (dissolution) respectively assigned to Brahmā, Vișnu and Rudra in the Hinduism. Then he seems to use the terms udaya/pralaya simply to mean 'production/destruction' in an ontological context. The following verses deal with various phases of spanda concerning the way of liberating realization. At the conclusion (SpK 51):

When he (the fettered soul) is firmly established in one place (the highest principle), then controlling the emerging (udaya) and merging (laya) of it (puryaștaka) he achieves the state of the enjoyer (bhoktrtā); therefore he is the 
lord of the wheel [of energies].

Here udaya/laya (pralaya) show a pair of opposite directions of the transition along the principles or categories (tattva) corresponding to each stage of yogin. We often find the terms udaya/pralaya in such a soteriological sense in Śaivāgama and similar treatises. Thus, Kallaṭa uses udaya/pralaya in two different contexts, that of ontology and that of soteriology. He thinks that each phenomenon of udaya/pralaya is real as it occurs; that the world is produced and destroyed in reality.

$\langle 2\rangle$ Utpaladeva is practically the founder of the Pratyabhijña-system. A basic idea of the system is the doctrine of $\bar{a} b h \bar{a} s a$ that every thing is a manifestion of real existence within the Supreme Subject of Consciousness and is real as it manifests. In the third chapter of his $\bar{I}$ śvarapratyabhijñāka arika (abbr. to IPK) and its Svavrtti, he attempts to connect views of the Pratyabhijñā-system with descriptions of the Śaivāgama. For instance, he explains that iśvara and sadāsiva, the fourth and the third principles (tattva) of 36 , are respectively the outward opening (unmeșa) and the inward closing (nimeșa) (IPK 3,1,3). He refers to Brahmā, Viṣnu and Rudra as the rulers over srsțti, sthiti and samhära, while he insists that these functions of the gods belong to the lower sphere of manifestation (ābhāsa) with diversity of objects (IPK $3,2,1)$. He intents to connect his views with the doctrine of spanda (IPK 1,5, 13-14). Utpaladeva explains the doctrine of $\bar{a} b h \bar{a} s a$ and connects views of the Pratyabhijñā with the earlier literature belonging to Śaivism.

〈3〉 Rājānaka Rāmakaṇṭha interprets SpK in line with Kallaṭa's Vrtti for the most part. In his own Vivrti, udaya is expressed in other terms such as utpatti, udbhava, utpāda and prādurbhāva, and pralaya is expressed in such terms as vināśa, vyaya, kṣaya and astamaya. Their meanings do not deviate far from Kallața's ideas. However, we should not overlook the fact that Rāmakantha was a direct disciple of Utpaladeva. It is likely that he produced his commentary on SpK under some influence of the doctrine of $\bar{a} b h \bar{a} s a$. 
〈4〉 Bhagavad Utpala attempts to validate the doctrine of spanda by quoting from Vaiṣnava scriptures along with Śaiva sources, and tries to show their compatibility. He was either a contemporary of Utpaladeva or lived after him. It is probable that his view is influenced by the doctrine of $\bar{a} b h \bar{a} s a$, as can be inferred from the synonyms of udaya/ pralaya used in his commentary on SpK. He admits the real creation and destruction of the world because he uses the word jagat-srști-samhāara, etc. He also accepts the three great functions (krtya). He regards udaya/ pralaya as a pair of soteriological courses to be realized by the Tantric yogin who aims at both enjoyment (bhoga) and liberation (mokșa). $\mathrm{He}$ attempts not only to connect the Vaiṣnava tradition with the Saiva, but also the doctrine of $\bar{a} b h \bar{a} s a$ with that of spanda. More noteworthy is that he interprets udaya/pralaya in two different contexts regarding ontology and soteriology in the same way as does Kallața.

$\langle 5\rangle$ Abhinavagupta quotes from $\mathrm{SpK}$ in his İsvarapratyabhijñāvimarśinz $1,5,14$ to explain the concept of sphuratta (luminous vibrating) in IPK, and he identifies spanda (or spandana) with his key term vimarśa (intentional act of consciousness) being equivalent to svātantrya (free will). He regards spanda broadly as a dynamic principle ruling various phases of the universe such as physical movements, mental functions, transcendental divinity, and so on. But he emphasizes the concept of vimarśa or svātantrya rather than that of spanda, making efforts to systematize unsettled views on pratyabhij $\tilde{a} \bar{a}$ into a consistent philosophy. In other words, the doctrine of spanda is not important for him, and it is replaced by the doctrine of vimarśa or svātantrya. He also attempts to connect the Pratyabhijña with the Śaivāgama, as did Utpaladeva. In IPV $3,1,3$, partially quoting $\operatorname{SpK} 1$, he explains that iśvara and sadásiva are respectively unmeșa and nimeșa causing the udaya and pralaya of the universe, and he calls both of them 'pure spanda'. He generally follows Utpaladeva's innovative views, while he elaborates the Pratyabijñāsystem discreetly compromising with other systems or traditions.

〈6〉 Kṣemarāja was eminent for his extensive and profound knowledge 
(4) udaya and pralaya in the Spanda-sâstra (H. ToDA)

in expounding various texts. He defines spanda as the power (śakti) of manifestation (ābhàsa) which causes contraction (samkoca) and expansion (vikāsa) leading to subjectivity and objectivity in every phase of both pure and impure categories, and as the power that simultaneously has a pair of relative aspects namely unmeșa and nimeșa. According to his Spandanirnaya on SpK 1 it is to be expounded that the udaya of the world is emanation (sarga) with diversity caused by the merging of essential unity, and that pralaya is disappearance of externality and appearance of essential nature. However, he says that in reality nothing arises (udeti) or perishes (vyayate) but it is only the power of spanda that effects each manifestation (ābhāsa) in the Supreme Being, as if it arose or perished; consequently, the great functions (krtya) are reduced to udaya/pralaya in pairs. He thinks that udaya/pralaya are relative situations and mutually exchangeable by different viewpoints. He expounds SpK by full use of the doctrine of $\bar{a} b h \bar{a} s a$. He reforms the Spanda-system so as to adjust it to the Pratyabhijñă-system.

$\langle 7\rangle$ We have noticed differences of view on udaya/pralaya between Kallata and other commentators, namely, between the original Spanda advocator and post-Pratyabhijñā thinkers. Kallața regards udaya and pralaya as production and destuction in reality. Rāmakaṇtha and Bhagavad Utpala are influenced by the doctrine of $\bar{a} b h \bar{a} s a$ (manifestation), while they admit the production and destruction or the great functions (krtya) of the Supreme God in reality. On the other hand, Utpaladeva and Abhinavagupta, the Pratyabhijñā thinkers, have their own ideas of $\bar{a} b h \bar{a} s a$ and vimarśa, and approach the Spanda-system in order to compromise with it. Finally, Kșemarāja emphasizes the doctrine of $\bar{a} b h \bar{a} s a$ and successfully synthesizes spanda and pratyabhiñ $\bar{a}$.

(This research was supported in part by a Grant-in-Aid for Encouragement of Young Scientists from the Ministry of Education, Science, Sports and Culture.)

〈Key Words〉 spanda, pratyabhijñāa ābhāsa, Kṣemarāja.

(Research Fellow, The Easterm Institute) 